\title{
Effect of Sprinkler Irrigation Levels on the Performance of Rice Genotypes under Aerobic Condition
}

\author{
G. Senthil Kumar ${ }^{*}$, T. Ramesh, K. Subrahmaniyan and V. Ravi \\ Tamil Nadu Rice Research Institute (TNAU), Aduthurai - 612 101, Tamil Nadu, India \\ *Corresponding author
}

\section{Keywords}

Irrigation levels, Sprinkler irrigation,

Pan evaporation, Yield, Economics

\section{Article Info}

Accepted:

16 February 2018

Available Online:

10 March 2018

\section{A B S T R A C T}

A Field experiment was conducted at Tamil Nadu Rice Research Institute, Aduthurai during Kharif, 2015 - 2016, to study the response of rice under different levels of irrigation through applied sprinkler system. Three levels of irrigation $\mathrm{I}_{1}$ - Surface irrigation method, $I_{2}$ - Sprinkler irrigation at $125 \%$ pan evaporation, $I_{3}$ - Sprinkler irrigation 150 per cent pan evaporation in main plot and five rice entries viz., ADT 43, ADT 45, Anna (R) 4, CORH 3 and $\mathrm{CO}(\mathrm{R}) 51$ were evaluated in strip plot design with three replications. The results revealed that in aerobic rice cultivation, grain yield of $3844 \mathrm{~kg} \mathrm{ha}^{-1}$ was recorded in CORH 3 under surface irrigation method which was followed by $\mathrm{CO}(\mathrm{R}) 51$ with a grain yield of $3418 \mathrm{~kg} \mathrm{ha}^{-1}$. Under sprinkler irrigation levels at $150 \%$ pan evaporation in CORH 3 recorded $25.1 \%$ lesser grain yield $\left(2875 \mathrm{~kg} \mathrm{ha}^{-1}\right)$ when compared to surface irrigation method. Among the genotypes, CORH 3 hybrid performed better under sprinkler irrigation followed by $\mathrm{CO}(\mathrm{R}) 51$. The varieties $\mathrm{ADT} 45$ and ADT 43 registered lower grain yield. Surface irrigation method utilized higher amount of irrigation water $1382 \mathrm{~mm}$ and 1335 $\mathrm{mm}$ whereas, sprinkler irrigation at $150 \%$ pan evaporation utilized $1097 \mathrm{~mm}$ and $1068 \mathrm{~mm}$ during kharif 2015 and 2016, respectively. Water saving of around $20.6 \%$ and $20.1 \%$ registered under sprinkler irrigation at 150\% pan evaporation during kharif 2015 and 2016, respectively when compare to surface irrigation method.

\section{Introduction}

Rice is the staple food for $65 \%$ population in India. It occupies an area of $45 \mathrm{~m}$.ha with an average production of 105 m.t. in India. Tamil Nadu is one of the biggest producers of rice in India. Demand for rice is growing every year and it is estimated that in $2025 \mathrm{AD}$ the requirement would be 140 m.t. Rice cultivation requires large quantity of water and for producing one $\mathrm{kg}$ of rice, about $3000-$ 5000 litres of water is required depending on the method of rice cultivation. Because of the increasing demand for food with the increasing population growth and scarcity of water, rice producers face three major challenges: i) To face water scarcity, ii) To increase productivity, iii) To produce more rice with less water. Hence, it is necessary to develop an alternative rice production system that requires less water and increases water productivity. Micro irrigation techniques is one such tool that can reduce water use and at the same time increase yield. Drip and 
sprinkler irrigation are needs to be tested for its suitability in rice cultivation. Sprinkler irrigation for rice production can be a water saving alternative to conventional flood irrigation (Mc Cauley, 1990). Recently, water scarcity in Cauvery delta zone threatens the rice cultivation which forced the farmers to find alternate methods of rice cultivation which requires lesser water. Under these situations, it is highly necessary to study the feasibility of sprinkler irrigation for rice cultivation. It is also essential to screen the suitable rice genotypes for sprinkler irrigation method under aerobic condition. Hence, a study was carried out to study the feasibility of sprinkler irrigation for rice cultivation in Cauvery delta zone.

\section{Materials and Methods}

Field experiments were conducted to study the feasibility of sprinkler irrigation for rice cultivation during Kharif season, 2015 and 2016 at Tamil Nadu Rice Research Institute, Aduthurai, Tamil Nadu. The field trial was laid out in strip plot design with three replications. The main plot treatments consisted of three levels of irrigation $I_{1}$ Surface irrigation method, $\mathrm{I}_{2}$ - Sprinkler irrigation at $125 \%$ pan evaporation, $\mathrm{I}_{3}$ Sprinkler irrigation 150 per cent pan evaporation and sub-plot treatments consisted of five rice entries viz., ADT 43, ADT 45, Anna (R) 4, CORH 3 and CO(R) 51.

The experimental soil was clay loam in texture with $\mathrm{pH} 7.17$, organic carbon $0.32 \%$ and available N, P and K was 178, 37, $244 \mathrm{~kg} / \mathrm{ha}$, respectively. In all the sprinkler treatments, first irrigation was given on the date of sowing through sprinkler $(50 \mathrm{~mm})$ for better soaking and germination of seeds and the next irrigation given based on the pan evaporation, measured by using USWB open pan evaporimeter. In surface irrigation method, first irrigation is given on the date of sowing and next irrigation is given based on the soil moisture condition. Soil moisture was measured by using tensiometer in the field. Irrigation was given whenever tensiometer reading goes beyond $12 \mathrm{Kpa}$. Total water usage for each treatment was calculated by using water meter. Rainfall received during the cropping period is $141.4 \mathrm{~mm}$ and 212.6 $\mathrm{mm}$ and mean average temperature is $36.7^{\circ} \mathrm{C}$ and $36.5^{\circ}$ C during 2015 and 2016, respectively. Economics of sprinkler irrigation levels were worked out by using the current market price of inputs and rice grain. All the recorded data were analysed statistically as per the method suggested by Gomez and Gomez (1984).

\section{Results and Discussion}

\section{Growth and yield attributes}

Growth and yield parameters of rice genotypes varied considerably under different levels of sprinkler irrigation and surface irrigation method (Table 1). Among the sprinkler irrigation levels, $150 \%$ pan evaporation registered higher plant height over lower levels. More number of panicles / $\mathrm{m}^{2}$ (316) and number of filled grains / panicle (109) was recorded under surface irrigation method followed by sprinkler irrigation at $150 \%$ pan Evaporation. Among the different genotypes, CORH 3 recorded higher number of panicles / $\mathrm{m}^{2}$ (327) followed by $\mathrm{CO}(\mathrm{R})$ 51. Under aerobic rice cultivation, application of sprinkler irrigation method produced lesser yield attributes when compared to surface irrigation method.

\section{Grain yield}

Irrigation levels influenced the grain yield significantly under aerobic rice cultivation (Table 2). Higher grain yield was recorded under surface irrigation method when compared to sprinkler irrigation levels. 
Table.1 Growth and yield parameters of rice genotypes under different irrigation levels (Mean of two years)

\begin{tabular}{|c|c|c|c|c|}
\hline Treatment & $\begin{array}{l}\text { Plant height (cm) } \\
\text { at maturity stage }\end{array}$ & $\begin{array}{c}\text { No. } \\
\text { panicles } / \mathrm{m}^{2}\end{array}$ & $\begin{array}{c}\text { No. filled } \\
\text { grains/panicle }\end{array}$ & $\begin{array}{c}\text { No. ill filled } \\
\text { grains/ panicle }\end{array}$ \\
\hline \multicolumn{5}{|l|}{ Irrigation levels } \\
\hline Surface irrigation & 91.5 & 316 & 109 & 11 \\
\hline Sprinkler Irrigation at $125 \% \mathrm{PE}$ & 90.6 & 208 & 102 & 20 \\
\hline Sprinkler Irrigation at $\mathbf{1 5 0 \%} \mathrm{PE}$ & 92.2 & 227 & 104 & 19 \\
\hline Mean & 91.1 & 250 & 105 & 17 \\
\hline S.Em+ & 1.8 & 6.5 & 2.3 & 0.86 \\
\hline$C D(p=0.05)$ & NS & 14 & 4 & 2 \\
\hline \multicolumn{5}{|l|}{ Genotypes } \\
\hline ADT 43 & 88.6 & 243 & 102 & 22 \\
\hline ADT 45 & 89.4 & 264 & 103 & 21 \\
\hline $\operatorname{Anna(R)} 4$ & 95.7 & 272 & 105 & 20 \\
\hline CORH 3 & 92.3 & 327 & 110 & 12 \\
\hline $\mathrm{CO}(\mathrm{R}) 51$ & 87.2 & 321 & 108 & 13 \\
\hline Mean & 90.6 & 285 & 106 & 18 \\
\hline S.Em+ & 2.5 & 8.2 & 2.1 & 0.92 \\
\hline $\mathrm{CD}(\mathrm{p}=0.05)$ & 5.7 & 16 & 4 & 2 \\
\hline
\end{tabular}

Table.2 Grain yield $(\mathrm{kg} / \mathrm{ha})$ of rice genotypes as influenced under different irrigation levels (Mean of two years)

\begin{tabular}{|c|c|c|c|c|c|c|}
\hline Irrigation levels / Genotypes & ADT 43 & ADT 45 & $\operatorname{Anna(R)} 4$ & CORH 3 & $\mathrm{CO}(\mathbf{R}) 51$ & Mean \\
\hline Surface irrigation & 2837 & 2987 & 3293 & 3632 & 3372 & 3225 \\
\hline $\begin{array}{l}\text { Sprinkler irrigation at } \mathbf{1 2 5 \%} \\
\text { pan evaporation }\end{array}$ & 1932 & 1949 & 2113 & 2521 & 2306 & 2164 \\
\hline $\begin{array}{l}\text { Sprinkler irrigation at } 150 \% \\
\text { pan evaporation }\end{array}$ & 1971 & 2062 & 2261 & 2735 & 2530 & 2312 \\
\hline Mean & 2247 & 2333 & 2556 & 2963 & 2736 & \\
\hline & Irrigation & Variety & \multicolumn{4}{|c|}{ Irrigation $\mathrm{x}$ variety } \\
\hline S.Em+ & 112 & 125 & \multicolumn{4}{|c|}{213} \\
\hline $\mathrm{CD}(\mathrm{P}=0.05)$ & 227 & 256 & \multicolumn{4}{|c|}{437} \\
\hline
\end{tabular}

Table.3 Water usage and water saving under different irrigation levels in rice under aerobic condition

\begin{tabular}{|l|c|c|c|c|}
\hline \multicolumn{1}{|c|}{ Irrigation levels } & \multicolumn{2}{|c|}{ Kharif, 2015 } & \multicolumn{2}{c|}{ Kharif, 2016 } \\
\cline { 2 - 5 } & $\begin{array}{c}\text { Total water used } \\
(\mathrm{mm})\end{array}$ & $\begin{array}{c}\text { Water Saving } \\
\%\end{array}$ & $\begin{array}{c}\text { Total water } \\
\text { used (mm) }\end{array}$ & $\begin{array}{c}\text { Water Saving } \\
\%\end{array}$ \\
\hline Surface irrigation & 1382 & - & 1335 & - \\
\hline $\begin{array}{l}\text { Sprinkler Irrigation at } \\
\mathbf{1 2 5 \%} \text { pan evaporation }\end{array}$ & 1052 & 23.9 & 1022 & 23.5 \\
\hline $\begin{array}{l}\text { Sprinkler Irrigation at } \\
\mathbf{1 5 0 \%} \text { pan evaporation }\end{array}$ & 1097 & 20.6 & 1068 & 20.1 \\
\hline
\end{tabular}


Table.4 Economics (Rs./ha) of rice genotypes as influenced by irrigation methods (mean of two years)

\begin{tabular}{|c|c|c|c|c|c|c|c|c|c|c|c|c|c|c|c|}
\hline \multirow{2}{*}{$\begin{array}{l}\text { Irrigation } \\
\text { levels }\end{array}$} & \multicolumn{3}{|c|}{ ADT 43} & \multicolumn{3}{|c|}{ ADT 45} & \multicolumn{3}{|c|}{$\operatorname{Anna}(\mathbf{R}) 4$} & \multicolumn{3}{|c|}{ CORH 3} & \multicolumn{3}{|c|}{$\mathrm{CO}(\mathbf{R}) 51$} \\
\hline & $\mathrm{CC}$ & GR & $\begin{array}{l}\mathrm{B}: \mathrm{C} \\
\text { ratio }\end{array}$ & $\mathrm{CC}$ & GR & $\begin{array}{l}\mathrm{B}: \mathrm{C} \\
\text { ratio }\end{array}$ & $\mathrm{CC}$ & GR & $\begin{array}{l}\mathrm{B}: \mathrm{C} \\
\text { ratio }\end{array}$ & $\mathrm{CC}$ & GR & $\begin{array}{l}\mathrm{B}: \mathrm{C} \\
\text { ratio }\end{array}$ & $\mathrm{CC}$ & GR & $\begin{array}{l}\mathrm{B}: \mathrm{C} \\
\text { ratio }\end{array}$ \\
\hline $\begin{array}{l}\text { Surface } \\
\text { irrigation }\end{array}$ & 30376 & 42555 & 1.41 & 30376 & 50624 & 1.67 & 30376 & 53396 & 1.76 & 30376 & 64988 & 2.13 & 30376 & 47852 & 1.99 \\
\hline $\begin{array}{l}\text { Sprinkler } \\
\text { irrigation at } \\
125 \% \text { pan } \\
\text { evaporation }\end{array}$ & 35214 & 28980 & 0.82 & 35214 & 27678 & 0.79 & 35214 & 28518 & 0.81 & 35214 & 37968 & 1.08 & 35214 & 36064 & 1.02 \\
\hline $\begin{array}{l}\text { Sprinkler } \\
\text { irrigation at } \\
150 \% \text { pan } \\
\text { evaporation }\end{array}$ & 36312 & 29565 & 0.81 & 36312 & 28476 & 0.78 & 36312 & 31094 & 0.86 & 36312 & 41650 & 1.14 & 36312 & 39788 & 1.09 \\
\hline
\end{tabular}

(*Sprinkler unit initial cost is worked out based on depreciation value for the average of five years)

[*CC - Cost of cultivation; GR - Gross returns; B: C ratio - Benefit: Cost ratio] 
Among the genotypes, CORH 3 hybrid recorded higher grain yield followed by $\mathrm{CO}(\mathrm{R})$ 51. In the interaction effect showed that, under surface irrigation method in $\mathrm{CORH} 3$ recorded higher grain yield of $3632 \mathrm{~kg} / \mathrm{ha}$ which was followed by $\mathrm{CO}(\mathrm{R}) 51$ with a yield of 3372 $\mathrm{kg} / \mathrm{ha}$. Whereas under sprinkler irrigation levels, sprinkler irrigation at $150 \%$ pan evaporation recorded $24.6 \%$ lesser grain yield $(2735 \mathrm{~kg} / \mathrm{ha})$ when compared to surface irrigation method.

The reason is adoption of sprinkler irrigation method under aerobic rice cultivation could not be sufficient to meet out the yield potential; it might be due to the application of sprinkler irrigation during flowering period causes pollen shedding which resulted lesser grain yield.

Such findings were earlier reported by Bouman et al., (2005) and Yoichiro Kato (2009).

\section{Water usage}

Quantity of irrigation water used for aerobic rice cultivation varied with irrigation treatments (Table 3).

Surface irrigation method utilized higher amount of irrigation water $1382 \mathrm{~mm}$ and 1335 $\mathrm{mm}$ whereas, sprinkler irrigation at $150 \%$ pan evaporation utilized $1097 \mathrm{~mm}$ and $1068 \mathrm{~mm}$ during kharif 2015 and 2016, respectively.

Water saving of around $20.6 \%$ and $20.1 \%$ registered under sprinkler irrigation at $150 \%$ pan evaporation during kharif 2015 and 2016, respectively when compare to surface irrigation method. In general, sprinkler irrigation level registered lesser amount of water usage when compared to surface irrigation method.

\section{Economics}

Economic analysis pooled over two years (Table 4) revealed that, Surface irrigation method in CORH 3 hybrid recorded maximum net returns of Rs. 34,612/- and benefit: cost ratio of 2.13 , whereas under sprinkler irrigation levels at $150 \%$ pan evaporation recorded lesser net returns of Rs. 5338/- and benefit: cost ratio of 1.14 only. This is mainly due to yield increment under surface irrigation over sprinkler irrigation level at $150 \%$ pan evaporation.

It can be concluded that, sprinkler irrigation level at $150 \%$ pan evaporation under aerobic rice cultivation recorded lesser grain yield and net profit when compared to surface irrigation method during kharif season.

\section{References}

Bouman, B.A.M., Penga, S and Castarneda, R and R. M. Visperas. (2005). Yield and water use of irrigated tropical aerobic rice systems. Agricultural Water Management. 74(2): 87-105.

Gomez, K.A and Gomez, A.A. (1984). Statistical procedure for agricultural research. John Wiley and Sons, New York.

Mc Cauley, G. N. (1990). Sprinkler Vs. Flood irrigation in Traditional rice production regions of Southeast Texas. Agronomy Journal. 82 (4): 677-683.

Yoichiro Kato, Midori Okami, Keisuke Katsura. (2009). Yield potential and water use efficiency of Aerobic rice. Field Crops Research. 113 (3): 328-334.

\section{How to cite this article:}

Senthil Kumar, G., T. Ramesh, K. Subrahmaniyan and Ravi, V. 2018. Effect of Sprinkler Irrigation Levels on the Performance of Rice Genotypes under Aerobic Condition. Int.J.Curr.Microbiol.App.Sci. 7(03): 1848-1852. doi: https://doi.org/10.20546/ijcmas.2018.703.218 